\title{
The Perception of New Small Business by Trade Creditors in South Africa
}

\author{
Olawale Fatoki \\ Department of Business Management, Turfloop Campus, \\ University of Limpopo, Limpopo Province, South Africa \\ Email: Olawale.fatoki@ul.ac.za
}

\section{Doi:10.5901/mjss.2014.v5n16p27}

\begin{abstract}
The failure rate of new small business is very high in South Africa. Non-availability of debt finance from commercial banks and trade creditors is one of the causes of failure. There is the argument in finance literature that providers of credit such as commercial banks and trade creditors discriminate or are uninterested in new small businesses. The objective of the study was to investigate the perception of new small businesses by trade creditors in terms of benefit and risk. Data was collected through the use of self-administered questionnaires in a survey. Descriptive statistics was used for data analysis. The results indicated that trade creditors perceive new small businesses as beneficial to their business. However, trade creditors also perceive new small businesses as risky. The results suggest that inaccessibility to trade credit by new small businesses is not caused by a lack of interest or discrimination by trade creditors but by the perception of risk.
\end{abstract}

Keywords: new small business, benefit, risk, perception, South Africa

\section{Introduction}

South Africa suffers from high level of unemployment with an official unemployment rate of estimate of 24.1\% (Statistics South Africa, 2013). One of the best ways to address unemployment is to leverage the employment creation potential of small businesses and to promote small business development (FinMark Trust, 2006). Small, medium and micro enterprises (SMMEs) are expected to be an important vehicle to address the challenges of job creation, sustainable economic growth, equitable distribution of income and the overall stimulation of economic development in South Africa (Maas \& Herrington, 2006). According to the Organisation for Economic Cooperation and Development (2006), small and medium enterprises (SMEs) and entrepreneurship are now recognised worldwide to be a key source of dynamism, innovation and flexibility. SMEs are responsible for most net job creation and they make an important contribution to productivity and economic growth.

Gree and Thurnik (2003) argue that the contribution of the SME sector cannot be sustained without the creation of new SMEs. A new SME can be described as an SME that has been in existence for less than forty two months. Wong et al. (2005) point out that Schumpeter in 1934 was one of the earliest economists to argue for new firm creation. According to Schumpeter, new firms are the vital force behind the progress of capitalism. The innovative activity of entrepreneurs feeds a creative "destruction process" by causing constant disturbances to an economic system in equilibrium, creating opportunities for economic rent. In adjusting to equilibrium, other innovations are spun-off and more entrepreneurs enter the economic system. New SMEs introduce new products and develop new technologies. As an important source of innovation, new firms bring competitive pressure to bear on established firms. According to Maas and Herrington (2006), new SMEs are seen as a significant component of the solution to South Africa's development issues. New business creation is fundamental to the growth of the South African economy and its future socio-political stability. The creation and sustainability of new SMEs are vital to the economic prosperity of South Africa (Herrington et al. 2009). However, despite the noted contribution of new SMEs, the creation rate of new SMEs in South Africa is one of the lowest in the world (Turton and Herrington, 2013). In addition, about $75 \%$ of new SMEs created in South Africa fail within the first two years of operation. Various challenges and impediments prevent the creation of new SMEs as well as cause the high failure rates of new SMEs in South Africa. One of these is the non-availability of formal sector financing. Maas and Herrington (2006) and Herrington et al. (2009) point out that access to finance is a major problem for the South African entrepreneur. Lack of financial support is the second most reported contributor to low new firm creation and failure, after education and training, in South Africa.

According to De la Torre et al. (2008), conventional wisdom argues that the inadequate financing of SMEs is to a significant extent rooted in supply-side factors. Banks and other credit providers appear to be uninterested in SMEs. The 
way in which the financial system works is biased against externally financing SMEs. Thus, the focus of this study is to investigate how trade creditors perceive new SMEs in terms of benefit and risk. This perception will influence the decision to grant credit to new SMEs. Improving the availability of credit is of significance in reducing the high failure rate of new SMEs in South Africa.

\section{Objective of the Study}

The objective of the study is to investigate the perception of new SMEs by trade creditors in terms of benefit and risk. De La Torre et al. (2008) suggest that the benefit of the SME sector can be measured by the profitability, largeness, competitiveness, prospects and strategic importance of the sector to other organisations such as commercial banks and trade creditors. Risk is measured by the perception of the failure rate and the perceived riskiness (credit risk) of new SMEs.

\section{Literature Review}

According to Myers (1984), the pecking order theory (POT) suggests that there is no well-defined optimal capital structure; instead the debt ratio is the result of hierarchical financing over time. The foundation of POT is that firms have no defined debt-to-value ratio. Management has a preference to choose internal financing before external financing. When a firm is forced to use external financing sources, managers select the least risky and demanding source first. When it is necessary to issue external sources, debt issuance is preferred to new equity. Kauffman Foundation (2007) reveals that $75 \%$ of SMEs' start-up capital is made up in equal parts of owner equity and bank loans, trade credit or credit card debt. This underscores the importance of liquid credit markets to the formation and success of new firms.

Trade credit is important to the survival of new SMEs. Huyghebaert et al. (2007) point out that trade credit arises when a firm purchases goods and services for which payment is delayed. SMEs can make use of trade credit as a form of credit or as a convenient alternative to paying cash each time a purchase is made. It is a spontaneous source of financing, as it arises from ordinary business transactions. However, it is evident that a supplier who offers extended credit is likely to build the cost of such credit into the pricing structure of the goods or services. Trade credit is usually extended for an intermediate period of thirty to sixty days at which point payment is due. If payment is not made on the date, financing charges are applied and trade credit becomes an alternative method of financing business expenses. Frequently, suppliers will offer cash discounts typically one percent to two percent of the purchase price for early payment not more than fifteen days after delivery.

According to Selima (2007), trade credit theories can be broadly classified into four main groups. These are asymmetric information, transaction costs, price discrimination and finance. The asymmetric information theory occurs when sellers face uncertainty about their customers' creditworthiness and financial health. Because of asymmetric information sellers cannot reliably make the best selling decisions. Likewise, when buyers face uncertainty about their suppliers' products/services they cannot confidently make the best purchasing decisions. In such circumstances, trade credit is used to deal with this asymmetric information problem. Buyers will have a sufficient period of time to investigate and assess the quality of the product and its value for money and to pay when they are satisfied. On the other hand, sellers will gather valuable information about customers' financial health through their payment patterns and their abilities to take advantage of discounts for early payment when offered, and they will use credit periods as a signal to the market of high and consistent product quality or of long-term presence.

In articulating the transaction cost theory, Frank and Maksimovic (2004) argue that the combination of the supply of both goods and finance from one source can lead to cost advantages and to a reduction in transaction costs. Furthermore, when the transactions take place on credit, the timing of the payment is less uncertain which enables firms to improve their cash-flow forecasts and simplify cash management. In addition, if all bills are accumulated and paid for together, transaction costs are kept to a minimum. The unpredictability, which may be found in cash-based businesses and which may be due to fluctuations in daily sales (that result in unpredictable patterns of cash receipt) can be reduced through companies offering trade credit. According to the terms offered, suppliers have a better idea about when customers are likely to settle their bills. Better knowledge of customer behaviour gained from experience leads to better forecasts that reduce the need to carry large amounts of cash, and subsequently decrease the cost of holding precautionary cash balances.

Presenting the price discrimination theory, Selima (2007) contends that as demand for a product can vary, sellers can manipulate the product price through the variation of the credit terms offered to each separate customer. So varying the trade credit terms gives the seller a more flexible approach to pricing and to discriminate among customers, as it is 
much easier to adjust credit terms (based on the payment period) than product price in order to respond to fluctuating demand. Furthermore, there is a difference between offering credit terms and enforcing them. Suppliers may allow a customer to pay after the agreed date without a penalty; or they may vary their two-part-terms (discount for early payment) and offer higher discount rates to selected customers or even allow them to take an unearned discount. Thus, giving longer credit than that agreed or increasing the discount rate offered, is effectively the same as reducing the price of the product/service.

Providing explanation for the financing theory, Frank and Maksimovic (2004) state that when non-financial institutions offer credit, they play an intermediary role by obviating the need for buyers to obtain finance from their banks to pay for their purchases. Furthermore, customers that are rationed by financial institutions tend to turn to trade credit, considering it a cheap way of getting short-term funds. So suppliers that are financially sound and can relatively easily get access to external funds tend to play this intermediary role by financing their customers' stock through trade credit. Therefore, trade credit becomes an attractive way of obtaining required finance. Trade credit works as a facilitator, in that firms that are able to borrow do so and pass on the benefit to those that do not have access to funds in the same way.

According to Huyghebaert et al. (2007), recent evidence from developing countries suggests that trade credit provides a signal to the availability of more bank loans to new SMEs. Trade credit in economic environments with weak informational infrastructure and less developed banking systems can play an even more important role in SME financing because of its strength in addressing the information problem. New SMEs face high failure rates in the early years of their life. This high failure rate limits their access to bank loans and they therefore tend to rely on their suppliers for financing. In addition, suppliers are more lenient than banks towards financially distressed firms. Banks tend to follow a strict liquidation policy when debtors encounter financial distress; if upon default a borrower's liquidation value exceeds its going concern value, banks will liquidate the firm. Suppliers, on the other hand, earn positive rents from selling goods to their customers. These rents arise from the profits suppliers can earn on future sales of their product to the client firm. If a customer is liquidated upon default, such supplier rents are lost. Suppliers therefore have an implicit equity stake in their customers and therefore are more willing than banks to renegotiate their claims or grant additional debt when debtors get into financial problems. In other words, suppliers may be willing to reorganize the defaulted debt even when the firm's liquidation value exceeds its going concern value.

Similarly, Wilner (2000) argues that suppliers are more dependent on their customers than commercial banks. The sunken investments in the customer-buyer relationship also make suppliers more lenient towards financially distressed buyers. Finally, bank loans are frequently secured, and thus more senior than suppliers' credit. Seniority and collateralization may induce banks to liquidate a distressed company prematurely following default. Therefore new SMES may prefer trade credit financing during the early years when the risk of default is high. In addition, any formal collateral does not usually guarantee trade credit.

Wilson and Summers (2002) note that trade credit, however, is considered to be an expensive financing source if payments are not made within the stipulated credit window. The credit term most frequently adopted by suppliers is " $2 / 10$ net 30 ". This term represents a $2 \%$ discount for payment within the 10 -day discount period; the net period ends on day 30. Furthermore, the cost of the credit is usually imputed into the cost of goods sold on credit. This may indirectly make trade credit an expensive source of finance.

Berger and Udell (2006:2950) add that despite some of the disadvantages associated with trade credit; it is an extremely important source of finance for new SMEs. Furthermore, trade credit has received much less interest from researchers compared to commercial bank lending which provides only slightly more credit to SMEs. Trade credit may also provide a cushion during credit crunches, monetary policy contractions or other shocks that leave financial institutions less willing or less able to provide small business finance. During these times, large firms may temporarily raise funds in public markets such as commercial papers and lend these additional funds to SMEs through trade credit. Since only a limited number of new SMEs have access to loans from financial institutions, trade credit may often be the best or only available source of external funding for working capital.

\subsection{Credit evaluation by trade creditors}

Willacy (2009) notes that many of the procedures and processes associated with the other lending technologies appear to be utilized in underwriting trade credit. Credit scoring and similar quantitative techniques have long been a part of the underwriting process used by credit managers. For larger accounts, financial statements are analysed as part of the underwriting process. No doubt, soft information and mutual trust play a role in some trade credit underwriting similar to relationship lending. Willacy (2009) examines the criteria for lending from trade creditors. The researchers point out that if payment is made after delivery, the seller in effect is extending credit to the customer. There are two basic forms of trade 
credit. The first one specifies that full payment is due a certain number of days after delivery. For example "net 30" means full payment is due in 30 days after invoice. After that day the buyer is at default. The second form has three components; (1) the discount percentage (2) the discount period (3) the effective interest rate (an example is "2/10 net 30). This implies that there is a discount of two percent for payment within ten days and full payment is due in 30 days. After 30 days, interest starts accumulating. According to Willacy (2009) the criteria for lending by trade creditors include:

- Acceptable financial conditions.

- Projected financial statements (cash flow, income statement and balance sheet, working capital and profitability trend).

- Any report from credit rating agencies.

- Acceptable bank and trade references.

- A statement of the legal composition of the customer (limited liability, close corporation).

- Management of the firm.

- Statement that customer is not operating under bankruptcy law or creditor protection.

- Verification that no significant collection lawsuits or judgments are outstanding which would seriously impact upon the customer's ability to remain solvent.

- If the customer fails to meet the above credit criteria, the trade creditor will require the customer to provide security.

\subsection{Perception of new small business by trade creditors}

There is the argument in finance literature that suggests that commercial banks and trade creditors seem to discriminate against or are uninterested in SMEs. The way in which the financial system works is biased against externally financing SMEs (De la Torre et al. 2008). Nigrini and Schoombee (2002) and Angela Motsa and Associates (2004) point out that commercial banks are not geared to finance entrepreneurs due to the fact that they developed in an economy dominated by large firms and thus do not have the skills set for assessing start-ups and small enterprises. In addition, SMEs are risky and have high failure rates. The perception of these factors by commercial banks and trade creditors will indicate their desire to get involved with new SMEs. Beck et al. (2008) add that there is often the perception among policy-makers and SMEs that banks, especially large ones, are not interested in financing SMEs.

Reitan and Waago (2002) however argue against the conventional wisdom that banks and other providers of credit are not interested in the SME sector. Banks and other financial agents are firms whose normal purpose of existence is to maximise the wealth of their shareholders. In addition, as pointed out by Bbenkele (2007), SMEs form about $80 \%$ of all enterprises in South Africa and therefore should be of great importance to banks and other credit providers. Therefore, it is important to investigate empirically how credit providers perceive new SMEs. De la Torre et al. (2008) suggest that five factors can be used to measure the beneficial effects of new SMEs. The factors are profitability, prospects, strategic importance, competitiveness and the largeness of the sector. Strategic importance implies that new SMEs are important to trade creditors in the achievement of their long-term goals, which include increased profitability and market share. Competitive implies rivalry between two or more businesses striving for the same customer or market. This means that the SME sector is seen as a source of competition by credit providers. Therefore, credit providers have to find ways to attract the SME sector. Positive prospects imply that commercial banks and trade creditors perceive a bright future for SMEs. Large implies that the SME sector including new ones account for most of the business enterprises in South Africa. Profitable implies that the SME sector is perceived as a source of profitability for credit providers.

\section{Research Methodology}

The study used the quantitative research design and survey research method. Data for the research study was gathered in a survey through self-administered questionnaires. To measure the perception of benefits and risk of new SMEs by trade creditors, the seven point Likert scale ranging from " 1 strongly disagree" to "7 strongly agree" was used. The researcher focused on trade creditors in the wholesale, retail and manufacturing sectors. According to Selima (2007) these three sectors account for most of the trade credits. The population frame of trade creditors was obtained from the Border-Kei Chamber of Commerce, the Port Elizabeth Regional Chamber of commerce and the Enterprise Black Business Directory. The population of big firms and SMEs that are in the wholesale, retail and manufacturing was five hundred and forty one. Using the Raosoft sample size calculator at 5\% margin of error and $95 \%$ confidence interval the sample size for trade creditors was 225 . This is the minimum recommended sample size by the Raosoft sample size 
calculator. However, 315 questionnaires were distributed to the respondents. The empirical research for the study was conducted in two ways; a pilot study and the main survey. Data collection and analysis was carried out with the assistance of a professional data collection firm. According to Coakes (2005) the normality of the data can be determined by using the Kolmogorov-Smirnov test (if the sample size is above 100) and the Shapiro-Wilks test (if the sample size is below 100). If the significance level is greater than 0.05 using either of the two tests, then normality is assumed. This study used the Kolmogorov-Smirnov test to determine the normality of the data because the sample sizes were more than 100. The significance of the Kolmogorov-Smirnov test was greater than 0.05 in all the tests. This implies that the normality of the data can be assumed. Descriptive statistics was used for data analysis.

\section{Results and Discussions}

Out of 233 respondents to the survey, 222 grant trade credit and 11 respondents do not grant trade credit and were eliminated from the survey. The majority of the respondents were male, educated to diploma or degree level and their firms have been operating for longer than ten years.

Table 1: The perception of new SMEs by trade creditors in terms of benefits and risks

\begin{tabular}{|l|c|c|}
\hline Perception & Mean score & Standard deviation \\
\hline High failure rate & 5.16 & 0.986 \\
\hline Risky & 5.35 & 0.994 \\
\hline Strategic importance & 5.20 & 0.851 \\
\hline Competitiveness & 5.22 & 0.724 \\
\hline Positive prospects & 4.31 & 0.626 \\
\hline Large & 5.39 & 0.847 \\
\hline Profitable & 4.69 & 0.652 \\
\hline
\end{tabular}

In terms of benefit, the potential largeness (mean of 5.39 on a 7 point Likert scale) of the new SME market is perceived as the most important driver of benefits. In addition, trade creditors perceive SMEs as a competitive (5.22) and strategically important sector (5.20). The profitability and prospects of new SMEs are also positively perceived by trade creditors but with lower rankings. All the five measures of benefits have results above 4 . The results suggest that trade creditors perceive new SMEs as beneficial to their business. Risk was measured by the perception of the failure rate of new SMEs and the perceived riskiness (credit risk) of new SMEs. Risk will impact on the willingness of trade creditors to get involved with new SMEs. The results indicate that trade creditors perceive new SMEs as a risky sector with a high failure rate. The results of this study confirm the findings of previous empirical studies such as Hawkins (2002) and FinMark Trust (2006) that new SMEs are risky and have high failure rates. The results indicated that trade creditors perceive benefits in new SMEs. The results suggest that the perception of new SMEs by trade creditors is not always about risk but also about benefits. The results suggest that non-availability of debt finance to new SMEs is not caused by a lack of interest or discrimination by trade creditors but by risk.

\section{Conclusions}

The failure rate of new SMEs is very high in South Africa. One of the causes of failure is the non-availability of formal sector financing from commercial banks and trade creditors. There is the argument in finance literature that suggest that commercial banks and trade creditors seem to discriminate or are not interested in new SMEs. The objective of the study was to investigate the perception of new SMEs by trade creditors in terms of benefit and risk. The benefits of the SME sector was measured by the profitability, largeness, competitiveness, prospects and strategic importance of the sector to other organisations such as commercial banks and trade creditors. Risk was measured by the perception of the failure rate and the perceived riskiness (credit risk) of new SMEs. The results indicated that trade creditors perceive new SMEs as beneficial to their business. The results also indicated that trade creditors perceive new SMEs as a risky sector with high failure rate. The results suggest that non-availability of debt finance to new SMEs is not caused by a lack of interest or discrimination by commercial banks and trade creditors but perception of risk. 


\section{References}

Angela Motsa \& Associates. (2004). SMME finance sector background paper: A review of key documents on SMME finance 19942004.[online]. Available: http://www.finmarktrust.org.za (January 6, 2014)

Bbenkele, E.K. (2007). An investigation of small and medium enterprises perceptions towards services offered by commercial banks in South Africa. African Journal of Accounting, Economics, Finance and Business Research, 1(1): 13-25.

Berger, A. \& Udell, G. (2006). A more conceptual framework for SME financing. Journal of Banking and Finance, 30(11): $2945-2966$.

Coakes, S.J. (2005). SPSS Version 12.0 for windows Analysis without Anguish. Sydney: John Wiley \& Sons Australia Limited.

De la Torre, Augusto, Peria, Maria, \& Schmukler, Sergio. (2008). Bank involvement with SMEs: beyond relationship lending. [Online]. Available: http://www.worldbank.org (May 15, 2013)

FinMark Trust (2006). Fin scope small business survey report. [online]. Available: http://www.finmarktrust.org.za ( May 18, 2013)

Frank, Murray, \& Maksimovic, Vojislav. (2004). Trade credit, collateral and adverse selection. [online]. Available: http://www.ifee.uva.nl/eml/papers/tcfeb26-2004.pdf (August 10, 2013)

Gree, A. \& Thurnik, C. (2003). Firm selection and industry evolution: the post country performance of new firm. Journal of Evolutionary Economics, 4 (4): 243-264.

Hawkins, P. (2002). Banks and small business. South African Journal of Economics, 70(3): 519-542.

Herrington, Mike, Kew, Jacqui, \& Kew, Penny. (2009). Global Entrepreneurship Monitor, South African report. [Online]. Available: http://www.gbs.nct.ac.za/gbswebb/userfiles/gemsouthafrica2000pdf (October 15, 2013)

Huyghebaert, N., Van de Gucht, L. \& Van de Hulle, C. (2007). The choice between bank debt and trade credit in business start-ups. Small Business Economics, 2(9): 435-452.

Kauffman Foundation. 2007. The capital structure decisions of new firms. [online]. Available: http://www.kauffman.org (November 20, 2013)

Maas, Gideon. \& Herrington, Mike. (2006). Global entrepreneurship monitor South Africa report. [online]. Available: http://www.gemconsortium.org/document.aspx?id756 (June 6, 2013)

Myers, S.C. (1984). Capital structure puzzle. Journal of Finance, 39(3): 575-592.

Nigrini, M. \& Schoombee, A. (2002). Credit guarantee schemes as an instrument to promote access to finance for small and medium enterprises: an analysis of Khula Enterprise Finance Ltd's. individual credit guarantee scheme. Development Southern Africa, 19(5): 735-750.

Organisation of Economic Cooperation and Development (2006). The SME financing gap volume 1 theory and evidence. [online]. Available: http://www.insine.org/documenti/sme_financing_gap_oced.pdf (July 13, 2013)

Raosoft (2013). Sample size calculation [online]. Available: http://www.ezsurvey.com/samplesize.html (May 17, 2013)

Reitan, Bjørnar, \& Waago, Sigmund (2002). Criteria used by private bank officer to evaluate new ventures: an empirical of gaps and shortcoming. [online]. Available: http://sbaer.uca.edu/research/icsb/1998pdf/111.pdf (January 15, 2013)

Selima, Y.P. (2007). Theories of trade credit. Journal of the Institute of Credit Management. 7(2):16-31.

Statistics South Africa. (2013). Quarterly labour force survey.[online]. Available: http://www.statssa.gov.za/publication/find publication asp [Accessed: 18 February 2014].

Turton, Natasha, Herrington, Mike (2013). Global Entrepreneurship Monitor 2012 South Africa. [online]. Available: http://www.gemconsortium.org/docs/download/2801 (November 15, 2013)

Willacy, M.P. (2009). Lending principles. available in financial distress: the case of trade credit. Journal of Finance, 55(1) $153-178$.

Wilner, B.S. (2000). The exploitation of relationships in financial distress: The case of trade credit. Journal of Finance, 55(1): $153-178$.

Wilson, N. \& Summers, B. (2002). Trade credit terms offered by small firms: Survey evidence and empirical analysis. Journal of Business Venturing and Accounting, 29(3): 317-351.

Wong, P.K., Ho, Y.P. \& Autio, E. (2005). Entrepreneurship, innovation and economic growth: Evidence from GEM data. Small Business Economics, 24(3): 335-350 